respective ability to be certain values that can be secured by and be the basis of law. This is conditioned by the existence of a philosophical concept of values, which depends on the substance of the law and the type of low understanding that directly affects the interpretation of the relationships between religious and low traditions and law, the recognition of their values for man and society.

Key words: low system, Christian-low tradition, axiology, axiological approach, methodology of jurisprudence, knowledge of low phenomena, low polycentrism, low consciousness.

DOI: 10.33.66.3/2524-017X-2019-10-185-190

УДК : 342.733.08:37](477)(045)

\author{
Олена Петрівна Науменко, \\ аспірант кафедри теорії, історії права і держави \\ та конституиійного права \\ Навчально-наукового інституту права \\ Університету державної фіскальної служби України
}

\title{
ЩОДО ПРАВОВОГО СТАТУСУ ОСВІТНЬОГО ОМБУДСМЕНА
}

Постановка проблеми. Для сучасного етапу національного державотворення характерно активне реформування усіх сфер суспільного життя, в ході якого перетворюються, вдосконалюються, а іноді і докорінно змінюються, форма та зміст суспільних відносин, зазнають перебудови відповідні державні системи та структури. Не оминули перетворення і освітньої сфери. В 2017 році набрав чинності новий рамковий Закон України «Про освіту», однією з новацій якого $є$ запровадження інституту освітнього омбудсмена [1]. Відповідну постанову було прийнято і на засіданні Уряду 6 червня 2018 року [2].

Міністр освіти і науки України Лілія Гриневич в контексті даного нововведення зазначила, що «наразі... активно відбувається децентралізація - значні повноваження та кошти передаються на місця, університети та наукові установи теж стають дедалі більш автономними. Це необхідно - на місцях краще зрозуміло, як ефективно використати ресурси. Але, на жаль, ми стикаємось і зі зловживаннями. Тому мають бути розвинені інструменти, що стануть своєрідними запобіжниками та захистять права учнів, студентів, освітян та науковців» [3].

Про назрілу необхідність створення в нашій країні інституту освітнього правозахисника відзначалось у офіційних джерелах ще у липні 2015 року [4]. Згодом його запровадження було ініційовано МОН України, підтримано урядом та отримало законодавче закріплення.

Введення інституту освітнього омбудсмена $є$ прогресивним кроком на шляху демократизації освітнього процесу, вагомим зрушенням у сфері захисту прав учасників освітнього процесу та для його становлення як дієвого та незалежного важливе значення має з'ясування його теоретичного підгрунтя, правової природи, місця та ролі в загальному механізмі забезпечення прав і свобод людини та громадянина.

Аналіз останніх досліджень і публікацій. Серед джерел, що стали основою для вивчення даної тематики, важливе місце належить працям учених, які досліджували проблематику функціонування інституту омбудсмена в Україні та зарубіжних країнах. Так, питання конституційно-правового статусу омбудсмена загальної компетенції висвітлювали - В. Бойцова, К. Закоморна, О. Марцеляк, Д. Феоктистов; проблемам діяльності спеціалізованих омбудсменів та певних їх видів приділяли увагу - Л. Голяк, Н. Ковалко, П. Ліхтер, Н. Лесько, Я. Неділько, О. Пономарьова та інші.

Інститут освітнього омбудсмена також вже ставав предметом дослідження науковців, зокрема, передумови його становлення вивчав О. Хомишин, повноваження у сфері захисту прав дитини Н. Коломоєць, роль освітнього омбудсмена у системі забезпечення прав здобувачів освіти аналізували Ю. Рижук, І. Полякова. Однак, у зв'язку з новизною даного інституту правовий статус освітнього омбудсмена ще не підлягав комплексному аналізу.

Метою статті $\epsilon$ здійснення теоретико-правового аналізу правового статусу освітнього омбудсмена, виокремлення його основних структурних елементів. 
Основні результати дослідження. Освітній омбудсмен $є$ різновидом інституту спеціалізованого омбудсмена.

На даний час для багатьох країн характерна практика введення спеціалізованих омбудсменів, які покликані захищати права та інтереси окремих категорій громадян, що потребують додаткового захисту, або які здійснюють свої функції «в межах окремої групи суспільних відносин для захисту специфічних прав громадян» [5, с. 67].

Їх види досить різноманітні - омбудсмени з питань охорони здоров'я (Велика Британія, США), омбудсмени з прав дитини (Норвегія, Фінляндія, Нова Зеландія, Австрія та інші країни), студентські омбудсмени (США, Велика Британія, Канада, Російська Федерація) [6, с. 30], омбудсмени із забезпечення рівності статей (Швеція, Фінляндія), у справах споживачів (Швеція, Норвегія, Фінляндія) [7, с. 99] та інші. Не оминула ця тенденція і Україну. За останнє десятиліття виникла ціла низка спеціалізованих омбудсменів і в нашій державі: «дитячий омбудсмен» (Уповноважений Президента України з прав дитини), Урядовий уповноважений з прав осіб з інвалідністю, Рада бізнес-омбудсмена, поліцейський омбудсмен та інші.

Але незважаючи на таку динаміку у появі нових видів вітчизняних спеціалізованих омбудсменів, науковці зазначають про певну невпорядкованість, хаотичність їх виникнення, а також не урегульованість питань створення та визначення правового статусу [5, с. 67].

Взагалі, в сучасній юридичній науці саме поняття правового статусу, визначення його структурних елементів не набули однозначного трактування та продовжують залишатися дискусійними.

Насамперед суперечки ведуться стосовно правового статусу людини та громадянина. С. Чикурлій, в дослідженні, присвяченому особливостям конституційно - правового статусу органів виконавчої влади, зазначає, що більшість авторів, як теоретиків права, так і конституціоналістів, переважно приділяють увагу аналізу структури правового статусу індивіда, тоді як структура правового статусу державних органів розглядається менше. Наявність деяких спільних рис вказаних правових статусів, на думку науковця, дозволяє стверджувати про цінність досліджень структури правового статусу індивіда для аналізу особливостей структури конституційно-правового статусу державного органу [8, с. 81], а з нашої точки зору - і правового статусу будь-якого суб'єкта права, у тому числі освітнього омбудсмена.

В цьому контексті слушно акцентує В. Висоцький, що «...структура правового статусу є загальним явищем, а зміст - індивідуальним. Саме за змістом правового статусу суб'єкти права відрізняються один від одного, тоді як структура об'єднує їх усіх» [9, с. 3-4].

Виходячи $з$ наведених позицій, вважаємо, що для з'ясування сутності та структури правового статусу освітнього омбудсмена доцільно розглянути розроблені наукою структури правового статусу особи, державних органів та інших суб'єктів права. Оскільки єдиного визначення не існує, зупинимося на деяких з них.

Юридична енциклопедія за редакцією Ю. Шемшученка визначає правовий статус як сукупність прав і обов'язків фізичних та юридичних осіб. Правовий статус осіб юридичних трактується через ïx «компетенцію, тобто права і обов'язки цих осіб, зафіксовані в чинному законодавстві. Йдеться про державні органи, підприємства, установи та організації... Від повноти юридичної фіксації повноважень даних юридичних осіб залежить ефективність їхньої діяльності» [10, с. 44].

3 цією позицією погоджується Г. Артюнян, який вважає, що правовий статус того чи іншого суб'єкта права визначається сукупністю прав та обов'язків, визнаних за ним законодавством [11, c. 465]. Деякі теоретики права до структури правового статусу особи, крім прав і обов'язків, включають також законні інтереси особи - О. Петришин [12, с. 237], юридичні гарантії - Ю. Тодика [13, c. 153], відповідальність - О. Скакун [14, с. 412].

А. В. Малько вважає, що права і обов'язки складають ядро правового статусу особи, яке доповнюється додатковими елементами: законні інтереси, правосуб'єктність, громадянство, юридична відповідальність та правові принципи [15, с. 127].

С. Коталейчук зазначає, шо права і свободи становлять основу статусу, але вони не можуть реалізовуватись без інших його компонентів - обов'язків та юридичної відповідальності, при цьому акцентує, що «йдеться виключно про ретроспективну відповідальність, тобто за вже вчинене діяння» $[16$, с. 289,297$]$.

В. Корельський характеризує правовий статус як категорію, що має збірний, універсальний характер: відображає індивідуальні особливості людини та її реальне положення у системі бага- 
томанітних суспільних відносин; права і свободи, що складають основу статусу, не можуть бути реалізовані без кореспондуючих правам юридичних обов'язків, без юридичної відповідальності в необхідних випадках, без правових гарантій; визначає права і обов'язки у системному вигляді, що дає можливість для порівняльного аналізу статусів різних суб'єктів 3 метою пошуку шляхів їх удосконалення [17, с. 549].

Немає серед учених-правознавців одностайності і щодо виокремлення складових елементів правового статусу омбудсмена.

На думку I. Хомишина, правовий статус омбудсменів у різних країнах встановлюється по-різному, має суттєві відмінності, що викликано певними суб'єктивними та об'єктивними чинниками: видом правової системи країни, особливостями правової культури та традицій, періодом заснування тощо. Об'єднуючим чинником у визначенні структури правового статусу будь-якого омбудсмена, з позиції науковця, $є$ виокремлення його функцій як важливих елементів, що визначають суттєві якісні характеристики цього інституту та віддзеркалюють його роль та соціальне призначення $[5$, с. 67$]$.

Російська науковець Г. Лічковаха зазначає, що саме функції, які виражаються в компетенції та повноваженнях, $є$ одним із найважливіших елементів статусу Уповноваженого з прав дитини $[18$, c. 901$]$.

О. Марцеляк, аналізуючи конституційно-правовий статус омбудсмена загальної компетенції, виділяє основні та другорядні елементи його статусу. До основних автор відносить ті, які «забезпечують юридичне оформлення та відбуття омбудсмана як повноправного суб'єкта права, обумовлюють його роль і місце в системі органів державної влади» - загальну правоздатність, права і обов'язки, гарантії діяльності. Неосновними ж визначає ті, які виводяться зі змісту і логіки повноважень i, як правило, не завжди мають юридичне закріплення - форми і принципи діяльності, відповідальність [19, с. 15].

Опираючись на думку науковця В. Кобрина, слід зазначити, що поняття «конституційний статус» є вужчим поняттям, ніж «правовий статус», адже останнє вміщує не лише конституційний, але й інші статуси (адміністративний, цивільний тощо) [20, с. 133].

В свою чергу Н. Богданова визначає конституційно-правовий статус ширшим поняттям ніж конституційний, оскільки він базується на нормах не лише Конституції, а й інших джерел конституційного права, та підсумовує, що обидва вони (і конституційний, і конституційно - правовий) являються складовими правового статусу, що найбільш узагальнено характеризує суб'єкта права [21, с. 4-5].

Л. Голяк вважає, що найбільш важливим елементом правового статусу спеціалізованого омбудсмена є його компетенція [22, с. 17], з цією позицією погоджується П. Ліхтер, яка, досліджуючи повноваження «дитячого омбудсмена», саме цю складову визначає ядром його правового статусу та приділяє значну увагу іiі вивченню [23, с. 59].

3 огляду на означене, більшість науковців у структурі правового статусу будь-якого суб'єкта права визначають його права та обов'язки (обсяг компетенції - щодо державного органу чи посадової особи).

Погоджуючись $з$ позицією О. Марцеляка, що права і обов'язки суб'єкта права - ніщо без гарантій, які виражаються у вигляді юридичних умов, засобів і способів реалізації суб'єктом права своїх прав та обов'язків [24, с. 87] та саме «гарантії прав забезпечують стабільність юридичної конструкції інституції омбудсмена» [19, с. 15], вважаємо за доцільне до основних елементів досліджуваного нами правового статусу освітнього омбудсмена, віднести, окрім його прав і обов'язків, також гарантії діяльності. Підставою ж для наявності правового статусу освітнього омбудсмена є його правосуб'єктність.

У розрізі тематики даного дослідження предметом нашої уваги є визначення законодавчо закріпленого обсягу компетенції та гарантій прав освітнього омбудсмена, що надасть можливість з'ясувати його роль та місце в системі органів державної влади, сукупність повноважень по реалізації покладених на нього функцій (завдань).

Правові засади діяльності освітнього омбудсмена визначено статтею 73 Закону України «Про освіту» [1] та затвердженими на виконання iï вимог постановою уряду [2] Положенням про освітнього омбудсмена та Порядком і умовами звернення до нього.

Відповідно до згаданої статті Закону інститут освітнього омбудсмена введено з метою забезпечення належних умов для реалізації права кожної особи на освіту (ст. 73 ЗУ «Про освіту). 
Законодавцем визначено, що освітнім омбудсменом є посадова особа, на яку Кабінетом Міністрів України покладається виконання завдань із захисту прав у сфері освіти [1;2 ].

Такий омбудсмен призначається урядом за поданням Міністра освіти і науки строком на п’ять років без права повторного призначення. Ним може стати громадянин України, який проживає в Україні останні п'ять років, вільно володіє державною мовою, має вищу освіту і досвід роботи у сфері освіти або науки не менше п'яти років [2].

Положення містить вимоги щодо несумісництва діяльності освітнього омбудсмена з будь-якою посадою в системі органів державної влади, із статусом депутата будь-якого рівня, 3 підприємницькою діяльністю, а також будь-якою діяльністю, що має на меті отримання прибутку, за винятком провадження викладацької, наукової чи творчої діяльності та отримання винагороди за неї [2].

Забезпечення діяльності омбудсмена здійснюватиметься Службою освітнього омбудсмена, порядок функціонування якої також визначено цим положенням [1].

Основними завданнями освітнього омбудсмена $є$ сприяння реалізації державної політики, спрямованої на забезпечення права людини на здобуття якісної та доступної освіти; здійснення заходів щодо додержання законодавства про освіту; вжиття заходів для забезпечення належних умов для рівного доступу до здобуття освіти; сприяння впровадженню інклюзивної форми навчання; сприяння виконанню Україною міжнародних зобов'язань щодо додержання в Україні прав людини на освіту та інші [2].

Відповідно до покладених на нього завдань освітній омбудсмен наділений правами: розглядати скарги та перевіряти факти, викладені у скаргах, поданих здобувачами освіти, їхніми батьками, законними представниками, а також педагогічними, науково-педагогічними і науковими працівниками; отримувати від закладів освіти та органів управління освітою інформацію, необхідну для виконання своїх функцій, у тому числі інформацію з обмеженим доступом; здійснювати перевірку заяв про випадки булінгу (цькування) в закладі освіти, повноту та своєчасність заходів реагування на такі випадки з боку педагогічних, науково-педагогічних, наукових працівників, керівництва та засновника закладу освіти; аналізувати заходи для надання соціальних та психолого-педагогічних послуг здобувачам освіти, які постраждали від булінгу (цькування), стали його свідками або вчинили булінг (цькування); за результатами проведених перевірок приймати рішення щодо обгрунтованості чи необгрунтованості скарги і на його основі надавати рекомендації закладам освіти та органам управління освітою, повідомляти правоохоронні органи щодо виявлених фактів порушення законодавства та іншими [1].

Слід зазначити, що процес нормотворчості даних положень триває і зараз відповідно до викликів часу. Так, у зв'язку з поширенням проявів булінгу у навчальних закладах, першопочатково закріплений перелік прав освітнього омбудсмена наприкінці минулого року, в грудні 2018 р., був доповнений пунктами, що стосуються прав освітнього омбудсмена у разі виявлення випадків булінгу (пП. 3, 4 ст. 73 3У «Про освіту») [1].

Натомість, необхідно зауважити, що на законодавчому рівні не в повній мірі визначено обсяг повноважень освітнього омбудсмена. Так, отримали закріплення лише загальні завдання та права омбудсмена, не врегульованими залишились питання обсягу його обов'язків. Крім того, не знайшли окреслення гарантії реалізації прав та одна із ключових характеристик ефективного функціонування будь-якого інституту омбудсмена (відповідно до Рекомендацій ПАРЄ № 1615 (2003) «Інститут омбудсмана» [25, п.п. 10 п. 7]) - забезпечення необхідності широкого інформування суспільства «про діяльність інституції, ііі рішення, висновки, пропозиції, рекомендації та доповіді».

Та не зважаючи на означені аспекти, введення цього правозахисного інституту ознаменувалося рядом позитивних зрушень, а саме:

- започатковано спеціалізований інститут щодо захисту прав у сфері освіти;

- у законодавстві, що регламентує діяльність освітнього омбудсмена, знайшли відображення такі характерні риси інституції омбудсмена: незалежність, політична нейтральність, дотримання конфіденційності у діяльності, співпраця з державними органами та громадськими організаціями в межах компетенції та інші;

- обрання термінf «омбудсмен», напротивагу «урядовий уповноважений» (у науковій літературі існує позиція про взаємозамінність термінів - «омбудсмен» та «уповноважений» [26, с. 75; 27 , c. 2]), оскільки уряд може мати цілий ряд уповноважених, та вони не завжди апріорі першочергово наділені саме правозахисними функціями та уповноважені розглядати скарги громадян; саме тер- 
мін омбудсмен найбільш в повній мірі відображає не лише шведське походження, а й специфічні особливості правової природи цього правозахисного інституту;

- розроблено детальний порядок звернення до освітнього омбудсмена, яким розробниками було здійснено спробу створити гнучку, позбавлену зайвого формалізму, з передбаченою можливістю зворотного зв' язку з заявником процедуру звернення до освітнього омбудсмена;

- окреслено Міністерством юстиції України наміри щодо синхронізації ініціативи МОН України про створення офісу освітнього омбудсмена із вже діючими проектами міністерства юстиції в сфері захисту прав дітей. Зокрема, мова йде про національний проект «Я маю право!», великий блок роботи якого стосується саме захисту прав дітей, серед найбільш важливих напрямків роботи якого - боротьба з корупцією в освітніх закладах, з булінгом і насильством над дітьми [28];

- підписано 7 серпня 2018 року Меморандум про співпрацю між Уповноваженим Верховної Ради України з прав людини та Міністерством освіти і науки України (до речі, це вперше підписаний меморандум між омбудсменом та державним органом) з метою консолідації зусиль в частині попередження, виявлення, усунення та недопущення порушень прав і свобод людини і громадянина у сфері освіти; співпраці за такими напрямками: моніторинг стану забезпечення прав людини на освіту, аналіз причин системних порушень та підготовка узгоджених пропозицій щодо усунення таких порушень; організація просвітницьких компаній та спільних заходів щодо підвищення правової поінформованості дітей стосовно своїх прав, а також педагогів щодо захисту прав дітей; взаємодія з громадськими організаціями 3 метою аналізу, обговорення напрацювань 3 питань дотримання прав людини у сфері освіти та інші [29].

Така співпраця надасть можливість в подальшому уникнути питань розмежування повноважень між освітнім омбудсменом та Уповноваженим Верховної Ради України з прав людини, про які відзначали науковці в ході аналізу діяльності інших видів спеціалізованих омбудсменів, зокрема «дитячого омбудсмена» [30, с. 95], та у розрізі реалізації спільних напрямків діяльності щодо підвищення правової поінформованості учасників освітнього процесу про свої права та способи їх захисту сприятиме реалізації освітнім омбудсменом правопросвітницької функції.

На даний час освітнього омбудсмена ще не призначено, це пов'язано з кадровими питаннями [31]. Сподіваємося, що з врахуванням значної персоніфікованості даної посади, адже вона повинна мати високий рівень довіри в суспільстві, кандидатуру все ж таки буде обрано.

Висновки. Отже, основними елементами правового статусу освітнього омбудсмена, що визначають межі його правових можливостей, роль та місце в системі органів державної влади, $є$ його права, обов'язки та гарантії діяльності. Обов'язки та гарантії прав ще підлягають окресленню та законодавчому закріпленню. Юридична фіксація обов'язків сприятиме належному виконанню омбудсменом своїх функцій, а правова регламентація гарантій діяльності - забезпеченню сталості даної інституції. Оскільки категорія «правовий статус» не є чимось статичним, постійним, iї зміст динамічно змінюється разом із розвитком суспільних відносин [32, с. 22], органічно, що змістове наповнення структурних елементів правового статусу освітнього омбудсмена підлягатиме уточненню та удосконаленню у ході реалізації омбудсменом своїх практичних завдань.

\section{Список використаних джерел}

1. Про освіту : Закон України від 5 вересня 2017 р. № 2145-VIII // База даних «Законодавство України» / ВР України [Електронний ресурс]. - Режим доступу : https://zakon.rada.gov.ua/laws/show/2145-19

2. Деякі питання освітнього омбудсмена : постанова КМУ від 6 червня 2018 р. № 491 // База даних «Законодавство України» / ВР України [Електронний ресурс]. - Режим доступу: https://zakon.rada.gov.ua/laws/show/491$2018-\% \mathrm{D} 0 \% \mathrm{BF}$.

3. 31 січня 2019 року в Україні з'явиться освітній омбудсмен, що захищатиме права учнів, студентів, освітян і науковців - Уряд прийняв відповідну постанову. Офіційний сайт МОН України [Електронний ресурс]. - Peжим доступу : https://mon.gov.ua/ua/news/z-1-sichnya-2019-roku-v-ukrayini-zyavitsya-osvitnij-ombudsmen-shozahishatime-prava-uchniv-studentiv-osvityan-i-naukovciv-uryad-prijnyav-vidpovidnu-postanovu.

4. Прем'єр-міністр Арсеній Яценюк в ефірі семи українських телеканалів про освіту. Офіційний сайт МОН України. Дата оновлення: 27.07.2015 [Електронний ресурс]. - Режим доступу : https://mon.gov.ua/ua/news/usinovivni-novini-2015-07-27-prem\%E2\%80\%99er-ministr-arsenij-yaczenyuk-v-efiri-semi-ukrayinskix-telekanalivpro-osvitu.

5. Хомишин I. Ю. Запровадження інституту освітнього омбудсмена в Україні / І.Ю. Хомишин // Прикарпатський юридичний вісник. - Вип. 4 (19). - 2017. - С. 66-69. 
6. Мариеляк O. В. Реформування вітчизняної моделі Уповноваженого з прав людини і запровадження дитячого омбудсмана в Україні - потреба часу / О. В. Марцеляк // Досвід інституту уповноваженого 3 прав дитини: перспективи для України : зб. матеріалів до міжнар. конф. - Київ, 11-12 жовтня 2006. - С. 29-33.

7. Пономарьова О. П. Інститут спеціалізованого омбудсмана / О.П. Пономарьова// Право і безпека. - 2011. - № 3 (40). - C. 95-100.

8. Чикурлій С. О. Конституційно-правовий статус органів виконавчої влади: дис. ... канд. юрид. наук : 12.00 .02 / Чикурлій Сергій Олександрович; Інститут законодавства Верховної Ради України. - К., 2008. - 214 с.

9. Висоцький В. М. Структура конституційно-правового статусу політичних партій / В. М. Висоцький // Південноукраїнський правничий часопис. - № 1. - 2015. - С. 3-6.

10. Юридична енциклопедія : в 6 т./ Редкол. : Ю. С. Шемшученко (голова редкол.) та ін. - К.: Укр. енцикл. імені М. П. Бажана, 2003/ - Т. 5: П-С. -733 с.

11. Артюнян Г. Г. Конституционное право. Энциклопедический словарь / Г. Г. Артюнян, М. В. Баглай. - М. : Норма, 2006. - $544 \mathrm{c}$.

12. Теорія держави і права : підруч. / О. В. Петришин, С. П. Погребняк, В. С. Смородинський та ін.; за ред. О. В. Петришина. - Х. : Право, 2015. - 368 с.

13. Тодыка Ю. Н. Конституционно-правовой статус человека и гражданина в Украине / Ю. Н. Тодыка, О. Ю. Тодыка; Национальная юридическая академия Украины им. Ярослава Мудрого, Академия правових наук Украины. - К. : Видавничий дім «ІнЮРЕ», 2004. - 367 с.

14. Скакун О. Ф. Теория государства и права : учеб. для вузов / О. Ф. Скакун; Университет внутренних дел. - Х. : Фирма «Консум», 2000. - 704 с.

15. Малько А. В. Теория государства и права : учеб. / А. В. Малько. - М. : Юристь, 2001. - 304 с.

16. Теорія держави і права : навч. посіб. / С. К. Бостан, С. Д. Гусарєв, Н. М. Пархоменко та ін. - К. : ВЦ «Академія», 2013. - $348 \mathrm{c.}$

17. Теория государства и права : учеб. для вузов / Под ред. проф. В. М. Корельского и проф. В. Д. Перевалова. -2-е изд., изм. и доп. - М. : Издательство НОРМА, 2002. - 616 с.

18. Личковаха А. В. Правовой статус уполномоченного по правам ребенка в субъектах РФ / А. В. Личковаха // ТЕХ RUSSICA. - Август 2014. - № 8 (Том XCIII). - C. 899-905.

19. Мариеляк $О$. В. Конституційно-правовий статус інституту омбудсмана: світовий досвід та українська модель: автореф. дис. ... д-ра юрид. наук : 12.00 .02 / О. В. Марцеляк; Одеська національна юридична академія. - Одеca, 2004. $-35 \mathrm{c}$.

20. Кобрин В. С. Поняття та зміст конституційно-правового статусу Прем'єр-міністра України / В.С. Кобрин // Вісник Національного університету «Львівська політехніка». Юридичні науки. - 2016. - № 837. - С. 131-136.

21. Богданова Н. А. Категория статуса в конституционном праве / Н. А. Богданова // Вестник Московского университета. - М. : Изд-во Моск. ун-та, 1998. - № 3. - С. 3-20.

22. Голяк Л. В. Інститут спеціалізованого омбудсмана: світовий досвід організації та діяльності: автореф. дис. .... канд. юрид. наук : 12.00.02 / Л. В. Голяк; Інститут держави і права ім. В. М. Корецького. - К., 2010. - 23 с.

23. Лихтер П. Л. Проблемы совершенствования законодательства о компетенции уполномоченного по правам ребенка в субъектах Российской Федерации / П. Л. Лихтер // Ленинградский юридический журнал. - 2015. № 2(40). - C. 59-70.

24. Марцеляк $О$. Основні елементи конституційно-правового статусу омбудсмана // Підприємництво, господарство, право. - 2003. - №11. - С. 85-88.

25. The institution of Ombudsman: Recommendation № 1615. 2003 //Parliamentary Assembly Council of Europe. URL: $\mathrm{http} / /$ assembly.coe.int/nw/xml/XRef/Xref-DocDetails-EN.asp?FileID=17133\&lang=EN; Рекомендація ПАР€ стосовно інституції омбудсмена (Рекомендація № 1615 (2003)). - Права людини в Україні. Інформаційний портал Харківської правозахисної групи [Електронний ресурс]. - Режим доступу : http://khpg.org/index. php?id=1168593186

26. Лесько Н. В. Загальна характеристика правового статусу Уповноваженого Президента України з прав дитини / Н. В. Лесько // Вісник Національного університету «Львівська політехніка». Юридичні науки. - 2015. № 827. - С. 74-78.

27. Cipa I. Б. Становлення інститут Уповноваженого з прав дитини в Україні / I. Б. Сіра // Державне управління: теорія та практика. - 2012. - № 2 [Електронний ресурс]. - Режим доступу : http://nbuv.gov.ua/UJRN/ Dutp_2012_2_20

28. Павло Петренко: Мін'юст готовий підтримувати усі ініціативи із захисту прав дітей. Офіційний сайт Міністерства юстиції України. 06.06.2018. 14:22 [Електронний ресурс]. - Режим доступу : https://minjust.gov.ua/ news/ministry/pavlo-petrenko-minyust-gotoviy-pidtrimuvati-usi-initsiativi-iz-zahistu-prav-ditey

29. Меморандум про співпрацю між Уповноваженим Верховної Ради України з прав людини та Міністерством освіти і науки України від 7 серпня 2018 р. Офіційний сайт Уповноваженого Верховної Ради України 3 прав людини [Електронний ресурс]. - Режим доступу : http://www.ombudsman.gov.ua/ua/publication/agreement/7818bp-memorandum-pro-spivpratsyu-mizh-upovnovazhenim-verxovnoii-radi-ukraiin 
30. Ковалко Н. М. Щодо правового статусу Уповноваженого Президента України з прав дитини / Н.М. Ковалко // Часопис Київського університету права. - 2013. - № 2. - С. 94-96.

31. Про новий стандарт базової освіти, інклюзію та антибулінг, держзамовлення та гранти для науковців Лілія Гриневич у ексклюзивному інтерв'ю PRM.UA. - 20 лютого 2019 р. 10:51 [Електронний ресурс]. Режим доступу : https://prm.ua/pro-noviy-standart-bazovoyi-osviti-inklyuziyu-ta-antibuling-derzhzamovlennya-tagranti-dlya-naukovtsiv-liliya-grinevich-u-eksklyuzivnomu-interv-yu-prm-ua/

32. Ортинська Н. В. Правовий статус неповнолітніх: теоретико правове дослідження : дис. ... докт. юрид. наук: 12.00.01 / Н. В. Ортинська; Національний університет «Львівська політехніка». - Л., 2017. - 524.

\section{References}

1. Pro osvitu: Zakon Ukrainy vid 5 veresnia 2017 r. № 2145 - VIII // Baza danykh «Zakonodavstvo Ukrainy» / VR Ukrainy [Elektronnyi resurs]. - Rezhym dostupu : https://zakon.rada.gov.ua/laws/show/2145-19

2. Deiaki pytannia osvitnoho ombudsmena: Postanova KMU vid 6 chervnia 2018 № 491 // Baza danykh «Zakonodavstvo Ukrainy» / VR Ukrainy [Elektronnyi resurs]. - Rezhym dostupu : https://zakon.rada.gov.ua/laws/show/491-2018$\% \mathrm{D} 0 \% \mathrm{BF}$

3. Z 1 sichnia 2019 roku v Ukraini ziavytsia osvitnii ombudsmen, shcho zakhyshchatyme prava uchniv, studentiv, osvitian i naukovtsiv - Uriad pryiniav vidpovidnu postanovu. Ofitsiinyi sait MON Ukrainy [Elektronnyi resurs]. Rezhym dostupu : https://mon.gov.ua/ua/news/z-1-sichnya-2019-roku-v-ukrayini-zyavitsya-osvitnij-ombudsmensho-zahishatime-prava-uchniv-studentiv-osvityan-i-naukovciv-uryad-prijnyav-vidpovidnu-postanovu

4. Premier-ministr Arsenii Yatseniuk v efiri semy ukrainskykh telekanaliv pro osvitu. Ofitsiinyi sait MON Ukrainy. Data onovlennia: 27.07.2015 [Elektronnyi resurs]. - Rezhym dostupu : https://mon.gov.ua/ua/news/usi-novivni-novini2015-07-27-prem\%E2\%80\%99er-ministr-arsenij-yaczenyuk-v-efiri-semi-ukrayinskix-telekanaliv-pro-osvitu

5. Khomyshyn I. Iu. Zaprovadzhennia instytutu osvitnoho ombudsmena v Ukraini / I.Iu. Khomyshyn // Prykarpatskyi yurydychnyi visnyk. - Vyp. 4 (19). - 2017. - S. 66-69.

6. Martseliak $O$. V. Reformuvannia vitchyznianoi modeli Upovnovazhenoho z prav liudyny i zaprovadzhennia dytiachoho ombudsmana v Ukraini - potreba chasu / O. V. Martseliak // Dosvid instytutu upovnovazhenoho z prav dytyny: perspektyvy dlia Ukrainy : zb. materialiv do mizhnar. konf. Kyiv, 11-12 zhovtnia 2006 r. - S. 29-33.

7. Ponomarova O. P. Instytut spetsializovanoho ombudsmana / O. P. Ponomarova // Pravo i bezpeka. - 2011. № 3 (40). - S. 95-100.

8. Chykurlii S. O. Konstytutsiino-pravovyi status orhaniv vykonavchoi vlady : dys. ... kand. yuryd. nauk: $12.00 .02 /$ Chykurlii Serhii Oleksandrovych; Instytut zakonodavstva Verkhovnoi Rady Ukrainy. - K., 2008. - 214 s.

9. Vysotskyi V. M. Struktura konstytutsiino-pravovoho statusu politychnykh partii / V.M. Vysotskyi // Pivdennoukrainskyi pravnychyi chasopys. - №1. - 2015. - S. 3-6.

10. Yurydychna entsyklopediia : V 6 t./ Redkol: Yu.S. Shemshuchenko (holova redkol.) ta in. - K.: «Ukr. entsykl.» imeni M. P. Bazhana, 2003 - T. 5: P-S. - 733 s.

11. Artyunyan G. G. Konstitucionnoe pravo. Enciklopedicheskij slovar' / G. G. Artyunyan, M. V. Baglaj. - M. : Norma, 2006. $-544 \mathrm{~s}$.

12. Teoriia derzhavy i prava: pidruchnyk / O. V. Petryshyn, S. P. Pohrebniak, V.S. Smorodynskyi ta in. ; za red. O. V. Petryshyna. - Kh. : Pravo, 2015. - 368 s.

13. Todyka Yu. N. Konstitucionno-pravovoj status cheloveka i grazhdanina v Ukraine / Yu. N. Todyka, O. Yu. Todyka; Nacional'naya yuridicheskaya akademiya Ukrainy im. Yaroslava Mudrogo, Akademiya pravovih nauk Ukrainy. K. : Vidavnichij dim «InYuRE», 2004. - 367 s.

14. Skakun O.F. Teoriya gosudarstva i prava: uchenik dlya vuzov/ O. F. Skakun; Universitet vnutrennih del. - H. : Firma «Konsum», 2000. $-704 \mathrm{~s}$.

15. Mal'ko A. V. Teoriya gosudarstva i prava: Uchebnik / A.V. Mal'ko. - M. : Yurist', 2001. - 304 s.

16. Teoriia derzhavy i prava : navch. posib. / S. K. Bostan, S. D. Husariev, N. M. Parkhomenko ta in. - K. : VTs «Akademiia», 2013. - $348 \mathrm{~s}$.

17. Teoriya gosudarstva i prava: uchebnik dlya vuzov / Pod red. prof. V. M. Korel'skogo i prof. V. D. Perevalova. - 2-e izd., izm. i dop. - M. : Izdatel'stvo NORMA, 2002. - $616 \mathrm{~s}$.

18. Lichkovaha A. V. Pravovoj status upolnomochennogo po pravam rebenka v sub»ektah RF / A.V. Lichkovaha // TEX RUSSICA. - Avgust 2014. - № 8 (Tom HSIII). - S. 899-905.

19. Martseliak $O . V$. Konstytutsiino-pravovyi status instytutu ombudsmana: svitovyi dosvid ta ukrainska model: avtoref. dys. ... d-ra yuryd. nauk : 12.00 .02 / O. V. Martseliak; Odeska natsionalna yurydychna akademiia. - Odesa, 2004. $-35 \mathrm{~s}$.

20. Kobryn V.S. Poniattia ta zmist konstytutsiino-pravovoho statusu Premier-ministra Ukrainy / V.S. Kobryn // Visnyk Natsionalnoho universytetu «Lvivska politekhnika». Yurydychni nauky. - 2016. - № 837. - S. 131-136.

21. Bogdanova N. A. Kategoriya statusa v konstitucionnom prave / N. A. Bogdanova // Vestnik Moskovskogo universiteta. - M. : Izd-vo Mosk. un-ta, 1998. - № 3. - S. 3-20. 
22. Holiak L. V. Instytut spetsializovanoho ombudsmana: svitovyi dosvid orhanizatsii ta diialnosti: avtoref. dys. .... kand. yuryd. nauk: 12.00 .02 / L.V. Holiak; Instytut derzhavy i prava im. V. M. Koretskoho. - Kyiv, 2010. - 23 s.

23. Lihter P. L. Problemy sovershenstvovaniya zakonodatel'stva o kompetencii upolnomochennogo po pravam rebenka v sub»ektah Rossijskoj Federacii / P. L. Lihter // Leningradskij yuridicheskij zhurnal. - 2015. - № 2(40). - S. 59-70.

24. Martseliak $O$. Osnovni elementy konstytutsiino-pravovoho statusu ombudsmana // Pidpryiemnytstvo, hospodarstvo, pravo. - 2003. - №11. - S. 85-88.

25. The institution of Ombudsman: Recommendation № 1615. 2003 //Parliamentary Assembly Souncil of Europe. URL: http://assembly.coe.int/nw/xml/XRef/Xref-DocDetails-EN.asp?FileID=17133\&lang=EN; Rekomendatsiia PARIe stosovno instytutsii ombudsmena (Rekomendatsiia № 1615 (2003)). - Prava liudyny v Ukraini. Informatsiinyi portal Kharkivskoi pravozakhysnoi hrupy [Elektronnyi resurs]. - Rezhym dostupu : http://khpg.org/index. php?id=1168593186

26. Lesko N. V. Zahalna kharakterystyka pravovoho statusu Upovnovazhenoho Prezydenta Ukrainy z prav dytyny / N. V. Lesko // Visnyk Natsionalnoho universytetu «Lvivska politekhnika». Yurydychni nauky. - 2015. - № 827. S. 74-78.

27. Sira I. B. Stanovlennia instytut Upovnovazhenoho z prav dytyny v Ukraini / I.B. Sira // Derzhavne upravlinnia: teoriia ta praktyka. - 2012. - № 2 [Elektronnyi resurs]. - Rezhym dostupu : http://nbuv.gov.ua/UJRN/Dutp_2012_2_20

28. Pavlo Petrenko: Miniust hotovyi pidtrymuvaty usi initsiatyvy iz zakhystu prav ditei. Ofitsiinyi sait Ministerstva yustytsii Ukrainy. 06.06.2018. 14:22 [Elektronnyi resurs]. - Rezhym dostupu : https://minjust.gov.ua/news/ministry/ pavlo-petrenko-minyust-gotoviy-pidtrimuvati-usi-initsiativi-iz-zahistu-prav-ditey

29. Memorandum pro spivpratsiu mizh Upovnovazhenym Verkhovnoi Rady Ukrainy z prav liudyny ta Ministerstvom osvity i nauky Ukrainy vid 7 serpnia 2018 r. Ofitsiinyi sait Upovnovazhenoho Verkhovnoi Rady Ukrainy z prav liudyny [Elektronnyi resurs]. - Rezhym dostupu : http://www.ombudsman.gov.ua/ua/publication/agreement/7818bp-memorandum-pro-spivpratsyu-mizh-upovnovazhenim-verxovnoii-radi-ukraiin/

30. Kovalko N. M. Shchodo pravovoho statusu Upovnovazhenoho Prezydenta Ukrainy z prav dytyny / N. M. Kovalko // Chasopys Kyivskoho universytetu prava. - 2013. - № 2. - S. 94-96.

31. Pro novyi standart bazovoi osvity, inkliuziiu ta antybulinh, derzhzamovlennia ta hranty dlia naukovtsiv - Liliia Hrynevych u ekskliuzyvnomu interviu PRM.UA. - 10:51 - 20 liutoho 2019 r. [Elektronnyi resurs]. - Rezhym dostupu : https://prm.ua/pro-noviy-standart-bazovoyi-osviti-inklyuziyu-ta-antibuling-derzhzamovlennya-ta-grantidlya-naukovtsiv-liliya-grinevich-u-eksklyuzivnomu-interv-yu-prm-ua/

32. Ortynska N. V. Pravovyi status nepovnolitnikh: teoretykopravove doslidzhennia: dys. ... dokt. yuryd. nauk: $12.00 .01 /$ N. V. Ortynska; Natsionalnyi universytet «Lvivska politekhnika». - L., 2017. - 524.

\section{Науменко О. П. Щодо правового статусу освітнього омбудсмена}

Статтю присвячено теоретичному дослідженню окремих аспектів правового статусу освітнього омбудсмена, виокремленню його основних структурних елементів. На підставі аналізу нормативно-правових актів, що регламентують діяльність освітнього омбудсмена, з'ясовано обсяг його повноважень. Проаналізовано проблемні питання законодавчого закріплення правового статусу освітнього омбудсмена.

Ключові слова: захист прав у сфері освіти, інститут омбудсмена, правовий статус, освітній омбудсмен.

\section{Naumenko O. P. On the legal status of education ombudsmen}

The article is dedicated to theoretical study of certain aspects of the education ombudsman legal status, and the distinction of his main structural elements. Based on the analysis of normative legal acts regulating the education ombudsman activity, the scope of his authority has been clarified. The problem issues of the legislative consolidation of the education ombudsman legal status have been analyzed. It appears that the main elements of the education ombudsman legal status, which determine the limits of his legal capacity, purpose and place within the system of state authorities are the rights, duties and activity guarantees. Duties and guarantees of rights still need to be outlined. The juridical fixation of duties will facilitate the proper performance of the ombudsman functions, and the legal regulation of activity guarantees-ensuring the sustainability of this institution. The legal status category is not something static, permanent, its content dynamically changes together with the social relations development, therefore it sounds seamlessly that the structural elements content of education ombudsman's legal status will be subject to refinement and improvement in the course of the ombudsman's implementation of his practical tasks.

Key words: protection of rights in the field of education, ombudsman institute, legal status, education ombudsmen.

DOI: $10.33 .66 .3 / 2524-017 \mathrm{X}-2019-10-190-197$ 